\title{
A Case Study Economic viability of the portable knapsack cotton picker
}

See end of the paper for authors' affiliations

Correspondence to : VINOD KUMAR VERMA

Department of Farm Machinery and Power Engineering, College of Technology and Engineering, Maharana Pratap University of Agriculture and Technology, UDAIPUR (RAJASTHAN) INDIA Email:sunilkawares@gmail. com

Paper History :

Received : 22.08.2014;

Accepted : 21.02 .2015
ABSTRACT : In India entire cotton is handpicked by human labour. It is not only a slow process but is extremely tedious work. Manual picking of cotton is labour intensive, requiring 1565 man-hours per hectare. The knapsack cotton picker was required to suit one-man operator. The cost economics of knapsack cotton picker was found as per the 'RNAM test code to determine the economical viability of the portable knapsack cotton picker machine. The cost of the machine was Rs. 8000 and the cost of picking was Rs. 10.88 per kg of cotton. The saving in cost and time compared to manual method of cotton picking was 12.96 and 69.85 per cent, respectively. The break-even point was $278.46 \mathrm{~kg} / \mathrm{annum}$ and payback period was 0.549 year.

KEY WORDS : Knapsack cotton picker, Cost economic, Break-even point and pay-back period

HOW TO CITE THIS PAPER : Verma, Vinod Kumar, Mathur, Ravi and Sharma, Ajay Kumar (2015). Economic viability of the portable knapsack cotton picker. Internat. Res. J. Agric. Eco. \& Stat., 6 (1) : 201-204. 